\title{
The Changing Image of the Ottoman Turks in the Habsburg Monarchy During the 18th Century
}

\author{
Alois Kernbauer \\ University of Graz, Austria
}

The old-aged confrontation between "East" and "West", between "civilization" and "barbarism", between "Christianity" and "Islam" came to new heights in the early modern times and found its arena in Central Europe. Since the late 15th century, the Ottoman Turks had been feared as menace, as the most dreadful enemies not only of the inhabitants of the Habsburg ruled countries but of the whole world of Christianity, and the Ottoman Turks did pose a permanent threat to their neighbours in Central Europe. The situation changed around 1700 when the Habsburgs succeeded in integrating the entire Hungarian Kingdom into their empire. From the early 18th century onwards the Ottoman Turks were no longer regarded as fierce fighters but increasingly as neighbours living in an unknown and totally different world and gained more and more curious attention. This change was not only the consequence of the new balance in power politics but mainly a sequel of gaining much more information. Up to the late 17th century the knowledge about the Ottoman Turks was based primarily on what had been reported by ambassadors travelling to Constantinople while in the 18th century people of several strands of life reported about their experiences. After the Peace of Passarowitz in 1718 trade agreements between the two states enabled activities of merchants and tradesmen who learned to know things about their eastern neighbours which were totally new to the Middle European contemporaries. Additionally, some elements of this "oriental" culture were taken over and were to become typical for Central Europe later on. The Turks were curiously observed as strange and fascinating neighbours. In the course of the movement of enlightenment from the middle of the 18th century onwards one aspect of this culture lost much of its dreadfulness: the fact that the Ottoman Turks were infidels. So it did not take very long until Ottomans were seen as being capable of true humanity regardless their religion. In the 19th century the multiethnic state organizations of the Ottoman Empire and the Habsburg Monarchy became outmoded in this age of nationalism. They realized their common interests and started a cooperation which eventually ended up as alliance in theWorld War I. From the point of view of power politics however, the Ottoman Empire was regarded as "sick man at the Bosporus". In the following the changes of the image are shown as an overview by observing the criteria against the background of the most important historical events. The details of how this process worked are still pretty murky. Further investigations are already on the way and will bring more light into the reasons and the mechanism of this development.

Keywords: East-West-conflict, Islam, Koran, Christianity, Ottoman Turks, Habsburg Empire, bridging the gap between the Ottoman Empire and Central Europe, Enlightenment characteristics, prejudices

There is one antagonism in our time which dates back in several variations to the ancient Greeks: the

Alois Kernbauer, professor, History Department, University of Graz, Austria. 
conflict between East and West which is the subject of the famous ancient Greek poem "Ilias". Each period of European history has experienced its own variety of this topic. For the Romans, the Parthians were one of the peoples representing the East and, after 375 a. C., the Huns left a negative impression on Germanic tribes. In the late 9th century, the Hungarians arrived in Central Europe and disturbed the ongoing state-building process in what was later to become Germany, France and Northern Italy, until they were crushed in 955 and settled in the Pannonian plane. From the late 11th century, when the period of the medieval crusades started, Christian Europe became aware of the world of Islam (Khoury, 2001, pp. 49-57) and for the very first time, information about the Arab world came to Europe. One of the consequences was that the Koran, 500 years after it had been written, was translated for the first time into Latin (Hofmann, 2012, p. 2; Haggag, 2011, pp. 20-28) with the intention of showing the dreadful errors of this holy book to the infidels (Khoury, 1995, pp. 30-75). Around 1241, the bad memories left by the Huns and the Hungarians were revived when the Mongols extended their empire from central Asia to Hungary and crushed all the armies of the European princes including Poland and Hungary. They did, however, fortunately retreat and never returned.

From the 14th century onwards, the Ottoman Turks started to conquer the Balkan peninsula, and, in 1453, occupied Constantinople and declared it as their capital. From this point on, they became a real threat to central Europe, first to Hungary and later to all the Habsburg ruled countries, and laid siege to Vienna for the first time in 1529. They became the embodiment of the danger from the East, not only for the population of Central Europe, but also for the whole of Christian Europe. This situation had consequences for all the nations which were neighbors of the Ottomans for several hundred years (Lisy-Wagner, 2013). The Turks were seen as the "Antichrist". The fear was aggravated by the fact that Western armies were no match to the predominant Ottoman troops and their new tactics. Consequently, the fear was aggravated by the feeling of helplessness which lasted until the late 17th century when the imperial Habsburg troops started to drive the Ottomans back. The negative image of the Ottoman Turks did not change for the better until the 18th century (Kopplin, 1987, pp. 150-159).

This antagonism experienced a dramatic comeback at the beginning of the twenty-first century after the al-Qaeda terrorist attacks of September 11th, 2001. The US government called upon its closest allies - the democratic powers of Western Christendom - to participate in a "global war on terror" against elements of radical Islam in the Orient (Johnson, 2011, p. 80).

This study examines one period of this conflict between "East" and "West" in Central Europe when the Ottoman Empire pushed its Western border into the Pannonian plain not far from Vienna.

The Ottoman expansion began in the 14th century, and some of the events continue to be recognized today in several ways in Central Europe.

The national holiday of the Serbs reminds them of the Battle of Kosovo on June 28th, 1389 when they were defeated by the Ottoman Turks. Only a few years later, the task of keeping the Ottomans out of Central Europe was taken over by the young Hungarian king Sigismund of Luxemburg, whose army consisting of Hungarians and French knights, was crashed in the Battle of Nicopolis south of the Danube in present Bulgaria in 1396 (Tuchmann, 1985, p. 501-502). Johnson (2011) refered to the long-lasting impact of the event:

The manner in which the Ottoman Sultan, Bajazet I, treated his vanquished enemies was responsible for making a deep, lasting, and bad impression on Western Christendom. Sultan Bajazet, enraged by his losses on the battlefield and indignant about the fact that the crusaders had massacred Turkish prisoners from a preliminary engagement, decided to take vengeance. Several thousand French prisoners, who were either too old to become slaves or not prominent enough to 
be held for ransom, were stripped naked, bound together by their hands and necks in groups of three or four, and marched in front of the Sultan. From early morning until late afternoon, executioners decapitated them, one by one, in the presence of the Sultan and the French nobles being held for ransom. Although crusaders were notorious for conducting themselves barbarously in the lands they traversed to, and their Christian missions and were usually just as ruthless with their enemies, Western Christendom was shocked by this "oriental" bloodbath. Indeed, incidents such as these provided the basis for the later Western perception of the Turkish threat. (Johnson, 2011, p. 72)

From the 16th century onwards, the image of the cruel, terrible, uncivilized Ottoman Turk, the incarnation of the infidel enemy of Christianity did not change very much, as very little was known about Muslim culture. This had been more or less the case since the Arab invasion in the 7th century after Christ when the cultural unity of the Mediterranean world broke. Though neither cultural nor commercial contact was ever completely absent between them, the two societies, Christian and Muslim, demonstrated an almost total unwillingness to understand each other. The reasons for this deliberate incomprehension were primarily religious. The contact between a handful of merchants and trade in a few luxury goods did nothing to dissolve the mutual distrust and dislike. Later, in the 12th century, two great areas of contact, Spain and Syria-Palestine, created greater opportunities for mutual understanding and for intellectual and technical borrowing, although in the heartlands of the two social attitudes remained substantially unaffected and unremittingly hostile.

Nevertheless, in Southern Italy, Sicily and in Toledo in Spain many Arabic texts were translated into Latin by bilingual monks from around 1100 onwards, thus making known thoughts and traditions of the ancient Greeks. These Latin versions of Aristotle, Hippocratic medicine in the revision of Avicenna and Dioscurides etc. spread across Europe within only a few decades. (Schipperges, 1964, pp. 150-170) These manuscripts had an immense impact on the European world of learning at a time when a new institution for highest education, the university, was established. In 1143, the first translation of the Koran into Latin after more than 500 years of its existence was completed and it long remained the only translation, full of errors and misunderstandings and, as previously mentioned, was translated only to primarily to demonstrate the errors of the infidel.

At the end of the later Middle Ages, when the Ottomans became neighbors of central European states the old-aged notion of the "thread from the east" was revived. Several historical events had never been forgotten, such as: the arrivals of the Huns in 375, of the Magyars in the 9th century, and of the Mongols in the 14th century to name just the most important ones. Another image revived in the course of Humanism and Renaissance was of the barbarians as being part of ancient Roman and Greek culture (Contadini \& Norton, 2013). The Turks were compared to the Scythians and to the Getae or Tomitae respectively as they appeared in Ovid's "Epistolae ex Ponto". These descriptions were enriched with specific characteristics of the Turks (Wiegand, 1993, pp. 12-31).

When the Ottoman reconnaissance units (Akindshi), the so-called "runners and burners", occasionally arrived in what is present day Austria from the 1470s onwards, they left a very bad impression on the population with their sudden and quick appearance on horseback, burning down houses, devastating harvests, pillaging and dragging young people into slavery (Unrest, 2001, pp. 75-95). One could say "warfare" as usual, and the population felt unprotected by their lords as the chivalry in its heavy armor was too clumsy to be a match for the quick and effectively operating Ottoman units. This way of warfare was to continue for centuries primarily along the border between the Habsburg ruled territories in Western Hungary, even in times of official peace between the Sultan and the Emperor. The Habsburg troops were continually required to closely monitor the situation at the "Military border", which became a heavy burden for the budget and accelerated the 
development of an effective financial system.

One contemporary description of the Eastern front, written around 1500, demonstrates the type of hyperbole used: "The Austrian countryside, far and near, is strewn with dead bodies, and its waters are colored with blood. The fields are devastated, villages and market-towns burnt, and our Holy Religion mocked and ridiculed" (Hantsch, 1959, p. 231). The themes of barbarism and sacrilege abound in the chronicles of the times which, aside from making the 'Infidel Turk' responsible for pillage and plunder and dragging Christians into slavery, acts portrayed as common Turkish practices, "quartering children or raping pregnant women and then cutting open their stomachs and tearing the unborn children out of their bodies. It would be unwarranted to make light of the people's suffering, but Turkish warfare was usually not any more or less than its contemporary Christian counterpart (Johnson, 2011, p. 79).

From the 16th century onwards the image of the cruel, terrible Ottoman Turk as the incarnation of the infidel enemy of Christianity did not change very much although, slowly but steadily more and more information about the unknown Muslim world arrived in Christian Europe. Ambassadors were the only informants. When King Francis I of France cooperated with the Ottoman Empire (Roulliard, 1941, pp. 45-65) against their common enemy, the Habsburgs, he sent some of his best musicians to Constantinople as a sign of good-will in 1543. Sultan Suleyman the Magnificent, after listening to this style of music, decided to send the musicians back home as he was afraid of the negative impact such decadent music may have on his subjects. The cultural gap between Christians and Muslims was obviously too great to allow constant contact.

In Central Europe, the "Turkish question" was omnipresent in the political discussions and part of negotiations at every Imperial Diet. Martin Luther issued writings against the Turks, many poets published on the subject more than 2,000 known treatises in Latin about the Turkish threat, not to mention the huge number of leaflets in German, and numerous contemporary songs (Göllner, 1978, pp. 12-45) about the cruel Turks were written (Göllner, 1978). They all conveyed an oversimplified image of the Ottoman Turks which was far from realistic. The reports of imperial ambassadors (Gröblacher, 1973, pp. 73-85; Gröblacher, 1983, pp. 159-169; Teply, 1968, pp. 7-79; Ekuripesic, 1983, pp. 12-33; Gevay, 1842, pp. 17-55; Nehring, 1983, pp. 79-88) dating from the early 16th century credited the Ottoman Turks as brilliant soldiers and riders, although in all other respects they lacked all the qualities of European civilized behavior. They were regarded as bloodthirsty beasts, and the home of Sultan Suleyman, the Magnificent home was said to be comparable to that of a wild animal (Wiegand, 1989, p. 117-139). This was, undoubtedly, of a compensatory function given the military superiority of the Ottoman Empire (Goffman, 2002, pp. 27-54).

The first step towards a more realistic notion was made by the Emperor's ambassador OgierGhiselin de Busbecq (Martels, 1989, pp. 9-34). He is renowned for the positive aspects which he brought back to Europe, such as the tulip (Pavord, 2003), which lead to the tulip mania of the 17th century. In 1554 and 1556, Busbecq resided in Constantinople, where he wrote his "Turkish Letters" (Busbecq, 1968, pp. 33-68). The intention of his writings was to encourage the European princes and citizens to intensify their efforts fighting against the Ottoman Turks for he believed that it was possible to beat them. Busbecq depicted for the very first time a new image: The Turks - strange and dangerous as they were-were not solely barbarians. His image of the Ottoman Turks was of the highest importance regarding what intellectuals Europe wide were thinking about them until the late 17th century Busbecq's description was intended to serve as a screen for his Christian contemporaries, in order to criticize their own flaws and decadent morals - just as it had done Tacitus in his "Germania" with the Romans. His letters are, therefore, more significantly concerned with the European self-image than being an 
extensive description of the Turks. The letters are one of the earliest texts that document the beginning of the process of European cultural self-awareness.

The second siege of Vienna in 1683, was a turning point in the relationship between the Ottoman Turks and Central Europe, particularly for the Habsburg ruled countries (Setton, 1991, pp. 123-144). When a huge army of about 300,000 approached Vienna in order to conquer it and to make it a center of another province of the Ottoman Empire, all the bad memories and images of the dreadful Ottoman Turks were revived. The population hastily strengthened the fortifications of the capital and of the other cities and towns-however, after months of warfare the landscape was devastated. The Ottoman army was eventually beaten in the battle of Vienna on September 12th, 1683 by the Christian army (Uhlich, 1783, pp. 23-77; Newald, 1883, pp. 17-45). This time, the Habsburgs were supported by troops of many Central European princes who disregarded their rivalry as they did not want to have the balance of power destroyed by losing the Habsburg territory to the Ottomans. Even the French - traditionally an ally of the Sultan against the Habsburgs - and their allies, the Polish, temporarily, switched sides.

From then on, the imperial troops drove the Ottomans back to the Balkan and were able to take over all the provinces which the Habsburgs had inherited in 1526. The Ottoman Empire no longer posed a threat to Central Europe and a new era began, which was characterized by an initial cooperation (Roider, 1995, pp. 55-70; Parvev, 1995, pp. 23-35) between the two regions (Tietze, 1985, p. 16) and by a slow, but steady transformation of the image of the Ottoman Turks based on an increasing number of detailed reports of ambassadors (Benigni, 1974, p. 11) and travelers. This transformation occurred in several areas of every-day life. As here is not the place for discussing the specifics of every single travelogue, let us have a look on the most important issues:

(1) Concerning: Equality of Rights

At the beginning of the 18th century, a gradual normalization process of the relationship between the Habsburg and the Ottoman Empire started. The first steps towards recognizing the Ottoman Turks as human beings - who existed in a different culture eventuated out of the necessities of everyday life as opposed to eventuating from enlightened ideas, which were still far from becoming the main stream of thinking. It was necessary to clear the circumstances and rules of a regular trade in order to guarantee legal security for the merchants. For the very first time, questions arose, such as whether oath taking by Moslems could be regarded as equal to that of Christians, which was a decisive step towards recognizing the religion of the others as equal (Ağa, 1966, p. 25).

(2) Communicating without An Interpreter

One of the preconditions of trade in the period was language skills and not every merchant could afford an interpreter. It was a member of the Jesuits Order who issued a stripped-down Turkish-Latin vocabulary containing short sentences in both languages to enable everybody to communicate in a standard form. It did not take long before Turkish-German, Turkish-French, Turkish-English versions followed (Clodius, 1728, pp. 7-55). When Maria Theresa of Austria created a school in Vienna for professional diplomats in 1754, the languages of the East, primarily Turkish and Persian, were regarded as being of the highest importance. All pupils were sent to the Austrian diplomatic mission in Constantinople to improve their language skills (Markom 2001, pp. 25-45), amongst them was Joseph Hammer-Purgstall, who rose to become the originator of the academic subject of Orientalism during the first decades of the 19th century (Mangold, 2004, pp. 34-49). 
(3) Traffic

In the course of 18th century the road system in Europe was actively improved. The cruising speed rose enormously and a regular public traffic service was established. From the middle of the 18th century onwards, everyone could travel from Vienna to Constantinople without having to individually organize the entire journey. Coaches and ships respectively departed from Vienna regularly (Verzeichnis, 1751).

(4) Repurchase of Prisoners of War

It was not until 1791 when the Turks acknowledged captured Christians as prisoners of war in the peace treaty of Sistowa. According to the Ottoman tradition, prisoners of war were regarded as slaves. Before 1791, the Ottoman offered the feasibility to buy slaves back (Feierlicher Einzug, 1720). The price for a slave depended on his or her age and social status could vary from about 700 florins to about 2,000 florins. The ransom was usually paid by the families of these prisoners (Freigekaufte, 1730). In the course of the 18th century charity organizations were formed to collect money for the repurchase of slaves whose relatives could not afford their release. In the course of the 18th century, these money collection activities lost much of their original function simply because the number of wars and the number of captured Christian soldiers diminished. These organizations increasingly became a platform for some of the highest members of society to demonstrate Christian humility and social engagement, but they also helped to preserve the memory of the "bad Ottoman Turks" at a time when the Ottoman image was, otherwise, changing for the better.

These prisoners not only brought home the experience of having lived in a totally strange and unknown culture, but some of them, additionally, enriched the Christians with Turkish habits. It was an Italian born imperial officer who, in 1684, published a small book about how to prepare coffee, thus introducing a great tradition (Report, 1720) into the German speaking world (Neumann, 1735).

(5) Examples of take over

Central Europe's population got to know was introduced to corn by the Ottoman Turks at the end of the 18th century. In some regions of present day Austria the word "Turk" continues to be used for what, in German, is normally referred to as "Mais" (maize).

Before the Scotman Eduard Jenner, it introduced the vaccination of smallpox in the last decade of the 18th century, another method existed - the inoculation. Physicians in Transylvania, the only Protestant province of the Habsburg Monarchy, were the very first who adopted this method shortly after the Turks had learned it from the Indians. Johann Adam Raymann, one of these physicians, published a treatise on it in the journal Annalesphysico-medicae Vratislavensis in Breslau in Poland in 1717. As a Protestant, he had studied medicine at Protestant universities in Northern Germany and in Leyden, in The Netherlands, and remained a member of the Protestant scientific community (Kernbauer, 2001, pp. 173-189). His treatise written in Latin-the lingua franca of the scientists in the early 18th century-was obviously never read by even one of the Viennese medical doctors, which may serve to illustrate the wide gap between Catholic and Protestant educated communities in the early 18th century in Central Europe. When Empress Maria Theresa and one of her daughters were hit by an outbreak of smallpox in 1768, she sent one of her doctors, Jan Ingen-Housz, to London to learn this method. Inoculation had been brought into England in 1718 by Lady Mary Wortley Montagu who had resided, from 1716 to 1718 in Constantinople, together with her husband, the British ambassador Eduard Wortley Montagu.

(6) Turkish fashion-Turkish mania

In the 1760s, curiosity about Turkish culture and the eagerness to obtain Ottoman goods rose to a level of 
Turkish mania. The differences in culture, as well as the frisson derived from the many earlier Turkish invasions, gave rise to a fascination among Central Europeans for all things Turkish—or what was regarded as being Turkish. This was part of a general trend in European arts at the time (Koppelkamm, 1987, pp. 7-24).

The increasing merchant exchange introduced Turkish draperies which were highly appreciated by the European upper-class (Gevers 1982, pp. 55-62). Even Empress Maria Theresa presented Turkish draperies to wives of European princes and to members of her own family. Women, including Maria Theresa and one of her daughters, dressed in what they regarded to be Turkish clothing. As the population was increasingly exposed to the world of the Ottoman Turks, they became fonder of elements of Turkish culture. Coffee drinking spread rapidly across all of Europe and became part of every-day life. In Vienna in the 1780s, numerous so-called Turkish coffee tents were constructed alongside the existing coffee houses. Shops were renamed to titles such as "The beautiful Mrs. Sultan" which was regarded as being extremely attractive.

In the last decades of the 18th century, there was literally no composer who did not write Turkish marches and dances which contained some elements of Turkish music whilst maintaining the typical sound of late 18th century European music (Bauer \& Deutsch, 1963). "Allaturca" is always lively in tempo, and is almost always a kind of march. When "Allaturca" music was scored for orchestra, it normally utilized extra percussion instruments not otherwise found in orchestras of the time: the bass drum, the triangle and cymbals. These instruments were traditionally used by Ottoman Turks in their military music, meaning that at least the instrumentation of "Turkish" music was authentic with the exception of the triangle. A piccolo, whose piercing tone recalls the shrill sound of the zurna (shawm) of Ottoman Janissary music, was often also incorporated. Military music was further emphasized by the strengthening of the percussion section and the usage of additional kettledrums.

Theatres played an enormous role in the life of the citizens from every strand of society in the 18th century. A certain genre of plays was performed on the stages in the outskirts of cities, and, in many of them, the Turks were stereotyped dramatis personae.

The opera, however, especially in the tradition of the exotic opera of the 18th century, was the first category to transform the traditional image of the Ottoman Turk beginning with the French opera, which increasingly gained influence in the Habsburg Monarchy from around 1750 (Meyer \& Sixt, 1996). Mozart's "The Abduction from the Seraiglo" (Preibisch, 1908), includes a Westernized version of Turkish music — based very loosely on the Turkish Janissary band music that he had employed in earlier work. Certain aspects of the opera conform to an eighteenth century European view of Orientalism. The Pasha's titular harem, for example, reprised themes of sexual libertinage, and the comically sinister overseer, Osmin, is a send-up of earlier stereotypes of Turkish despotism. However, the opera also defies the stereotyped expectations of a despotic Turkish culture, as its climax hinges around a selfless act of forgiveness and humanity on the part of the Pasha as a human, gentle and genuine human being. The opera, which was first performed in 1782, was a huge success.

In 1779, the German writer Gotthold Ephraim Lessing, an outstanding representative of enlightened ideas, published his play "Nathan the Wise" with the "Ring Parable" as the centerpiece. It was set in Jerusalem during the 3rd crusade around 1190 and described how the Jewish merchant Nathan, the enlightened Sultan Saladin and a Templar knight bridged their gaps between Judaism, Islam and Christianity and thus formulated a credo of general humanity, tolerance and charity values and of relativism of religions. 
The tide turned in every respect once several translations of mostly English written books on history and culture of the Ottoman Empire gave a balanced picture of the life there. Surprisingly, even the Koran was judged in a new way. The translations of the Koran that had been done since the Middle Ages were all finished with a disparage intention containing hostile comments only to highlight the errors of the infidels. It was Theodor Arnold who translated the George Sale's English version of Koran (Sale, 1742) into German and in his introduction, like George Sale he deplored that Mohammed had always been condemned as the "worst villain", notwithstanding that Mohammed had deceptively claimed to be a prophet and had given the Arabs the best religion and the best laws. (Arnold, 1746)

People, such as the poet Johann Wolfgang Goethe (Mommsen, 1988), eagerly read the Koran and praised the founder of Islam. He rejected the intention of the fanatical translator, David Friedrich Megerlin, a professor for Protestant theology at the University of Frankfurt, who regarded the Koran as a "book of lies" and intended "to teach the Germans to better know the Antichrist Mohammed ... and to ask God to make a quick end to this violent empire and its superstitious religion in the Koran .... that Jesus and his blessed gospel was the sole reigning gospel and would rise again; when Muslims, Jews and heathens were led to the sheep's stable of Christ in good time" (Mommsen, 2011, p. 3).

Goethe replied: "We only wish that one day a different translation might be completed under the eastern skies by a German who would read the Koran in his tent with all the poetic feeling of the prophet and who would have enough insight to grasp the entirety of it" (Mommsen, 2011, p. 4-5).

The process of transforming the bad image of the Turk into a good one resulted out of the necessities of everyday life and was enormously accelerated by the ideas of enlightenment.

What was, however, not altered was the fear of infectious diseases which was mostly spreading from Eastern and Southeastern Europe to the West and held the notion of the "thread from the East" alive.

The disadvantage of trade was the increasing danger of spreading epidemics, especially the most feared plague. There were custom facilities constructed at the border to control and sanitize persons and goods according to the standards of the early 18th century. In times of plague the entire border, longer than 1,000 km, was literally closed. Soldiers were deployed in visibility range 24 hours a day counting in sum an army of 20,000 men. These men were ordered to shoot everyone who tried to cross the border. This so-called sanitary cordon existed until the 19th century, when the Europeans pushed pressure on the Ottoman Empire to intensify the struggle against infectious diseases which repeatedly spread from the Ottoman Empire because of the Mekka pilgrimages.

Consequently, the general feeling of a permanent menace coming from the "East" once again received new nourishment and was enhanced, from around 1800 onwards, by more detailed information about every-day life in the East. One of the worst experiences was the first pandemic of cholera in the early 1830s. The increasing number of descriptions of Turkish every-day life was unflattering to the inhabitants of the Ottoman Empire, and the backward condition of the state became fully exposed to the world after Sultan Selim III. launched a reform program according to the model of Western states in 1789 (Rosen, 1866). Western physicians, philologists and scientists - especially botanists and geologists, travelled to the Ottoman Empire and published books which gained great attention (Die EuropäischeTürkei, 1829) and were entitled for e.g. "Turkey and its inhabitants" (Rigler, 1852). Simultaneously, such information created and strengthened the feeling of superiority towards the Ottoman Turks and their strange customs and traditions. 
The increasing knowledge about the weak state-organization of this vast supra-national empire without a modern system run by civil servants, in addition to the military inferiority of the Ottoman army and the permanent threat of epidemics from the East caused another transformation (Brix, 2001, p. 147). The exotic but civilized Ottoman Turk was now portrayed as the "weak man at the Bosporus. In the course of the 19th century the Ottoman Turks were condescendingly regarded as leading an inactive life, being lazy, sensual, lascivious and addicted to smoking opium. As a result, one could summarize: within little more than 100 years the image of the Ottoman Turks had turned from bad to good and, consequently, to bad again.

\section{References}

Ağa, O. (1966). Zwischen paschas und generälen. bericht des Osman Ă̆a aus Temeschwar über die Höhepunkte seines Wirkens als diwandolmetscher und diplomat. Übersetzt, eingeleitet und erklärt von Richard Franz Kreutel und Friedrich Kornauth. (Osmanische Geschichtsschreiber 5). Graz-Wien-Köln: Böhlau.

Arnold, Th. (1746). Der Koran, oder insgemein so genannte Alcoran des Mohammeds, unmittelbahr aus dem arabischen original in das Englische übersetzt, und mit beygefügten, aus den bewährtesten commentatoribus genommenen Erklärungs-Noten, wie auch einer Vorläufigen Einleitung versehen von George sale. Lemgo: Meyer.

Bauer, W. A., \& Deutsch, O. E. (1963). Mozart. briefe und aufzeichnungen (Gesamtausgabe) (Vol. 3, pp. 1780-1786). Salzburg: Internationale Stiftung Mozarteum.

Benigni, R. (1974). Österreichische botschaftsberichte über arabische Länder: Register zu den im Haus, Hof- und Staatsarchiv in Wien befindlichen Akten der Kaiserlichen internuntiatur, der späteren Botschaft, in Konstantinopel von 1750 bis 1918. (Biblos-Schriften 77).Wien: Österr. Institut für Bibliotheksforschung, Dokumentations-u. Informationswesen.

Brix, E. (2001). The decline of empires. Schriftenreihe des Österreichischen Ost- und Südosteuropa-Instituts 26. Wien: Verlag für Geschichte und Politik.

Busbecq, O. G. (1968). Omniaquaeextantopera. Um eine Einleitung vermehrter Nachdruck der Ausgabe Basel 1740. Graz: ADEVA.

Clodius, J. C. (1729). Grammaticaturcicanecessariisregulislinguaedifficultatesillustrans, ac aliquot coloquiis et senentiisturcicisaucta. Leipzig: Deer.

Contadini, A., \& Norton, C. (2013). The Renaissance and the Ottoman Worl. London: Asghate.

Kuripešić, B. (Ed.), (1983). Itinerarium der Gesandtschaft König Ferdinand I. von Ungarn nach Konstantinopel 1530. MaterialiaTurcica. Beiheft 6. Bochum: Studienverlag Brockmeyer.

Feierlicher Einzug (1729, June 15). Von 300 in der Türkei befreiten Christen. Wiener Diarium. Retrieved from http://anno.onb.ac.at/cgi-content/anno?aid=wrz

Freigekaufte (1730, September 27). Aus türkischer Gefangenschaft. Wiener Diarium, Anhang. Retrieved from http://anno.onb.ac.at/cgi-content/anno?aid=wrz

Gevay, A. V. (1842). Gesandtschaft König Ferdinands I. an Sultan Suleiman I. 1536-1537, 1539-1540, 1540-1541. 3 (Teile in einem Band). Wien: Schaumburg.

Gevers, V. (1982). The influence of Ottoman Turkish textiles and costume in Eastern Europe: with particular reference to Hungary (History, technology, and art ). Toronto: Royal Ontario Museum.

Göllner, C. (1978). Tvrcica: Die europäischen Türkendrucke des XVI. Jahrhunderts: 3. Die Türkenfrage in der öffentlichen Meinung Europas im 16. Jahrhundert.Ed. Acad.Republicii Socialiste România et al. Bucureşti.

Goffman, D. (2002). The Ottoman empire and early modern Europe (New approaches of European history 24). Cambridge: University Press.

Gröblacher, J. (1973). König Maximilians I. Gesandtschaft zum Sultan Bajezid II. In A. Nowotny, \& O. Pickl (Eds.), Festschrift Hermann Wiesflecker zum 60. Geburtstag (pp. 73-85). Graz: Histor. Inst. d. Univ. Graz.

Gröblacher, J. (1983). König Maximilians I. zweite Gesandtschaft zu Sultan Bayezid II (1504/05). In W. Höflechner, H. J. Mezler-Andelberg, \& O. Pickl (Eds.), DomusAustriae. Eine Festgabe Hermann Wiesflecker zum 70. Geburtstag (pp. 159-169). Graz: ADEVA.

Haggag, M. (2011). Die deutschen Koranübersetzungen und ihr Beitrag zur Entstehung eines Islambildes beim deutschen Leser (Angewandte Sprachwissenschaft) (Vol. 22). Frankfurt a. M. et al: Lang.

Hantsch, H. (1959). Die Geschichte Österreichs (Vol. 1). Graz et. al: Böhlau. 
Hofmann, A. Untersuchung der Übersetzungen des Qurans in die deutsche Sprache bis zum Ende des 18 Jahrhunderts. Retrieved from http://www.eslam.de/begriffe/q/pdf/altedeutschequrane.pdf

Johnson, L. R. (2011). Central Europe (3rd ed.). New York, Oxford: Oxford University Press.

Kernbauer, A. (2001). Wissenschaftstransfer als Folge studentischer Migration am Beispiel siebenbürgischer Intellektueller im 18 Jahrhundert. In Berichte zur Wissenschaftsgeschichte (Vol. 24, pp. 173-189). Weinheim: VILEY-VCH.

Khoury, A. Th. (2001). Der Islam und die westliche Welt: Religiöse und politische Grundfragen. Darmstadt: Primus-Verlag.

Khoury, P. (1989-2002). Matériaux pour server à l'étude de la controverse théologique islamo-chrétienne de langue arabe du VIIIe au XIIe siècle (8 Vols. Religionswissenschaftliche Studien 11/1-6.1.2.3). Würzburg-Altenberge: Echter-Telos.

Koppelkamm, S. (1987). Der imaginäre Orient: exotische Bauten des 18. und 19. Jahrhunderts in Europa. Berlin: Ernst.

Kopplin, M. (1987). Turcica und Turquerien. Zur Entwicklung des Türkenbildes und der Rezeption osmanischer Motive vom 16. bis 18. Jahrhundert. In Exotische Welten-Europäische Phantasien Ausstellungkatalog (pp. 150-159). Stuttgart: Cantz.

Lisy-Wagner, L. (2013). Islam, Christianity and the making of Czech identity.1453-1683. London: Ashgate.

Mangold, S. (2004). Eine "weltbürgerliche Wissenschaft"-Die deutsche Orientalistik im 19. Jahrhundert (Pallas Athene) (Vol. 11). Stuttgart: Verlag Franz Steiner.

Markom, E. (2001). Die diplomatischen Beziehungen Österreichs zum Osmanischen Reich im 18. Jahrhundert unter besonderer Berücksichtigung der Orientalischen Akademie in Wien. Thesis: Wien.

Martels van, Z. R. W. M. (1989). Leven en werk van de keizerlijkegezantaanhethof van Süleyman de Grote. Thesis, Groningen.

Meyer, R., \& Sixt, E. (Ed.) (1996). Bibliographiadramatica et dramaticorum.2. Abteilung (Vol. 6, pp. 1726-1729). In Reinhart Meyer (Ed.), Bibliographiadramatica et dramaticorum. Kommentierte Bibliographie der im ehemaligen deutschen Reichsgebiet gedruckten und gespielten Dramen des 18. Jahrhunderts nebst deren Bearbeitungen undübersetzungen und ihrer Rezeption bis in die Gegenwart. Tübingen: Niemeyer.

Mommsen, K. (1988). Goethe und 1001 Nacht (suhrkamp-taschenbuch 674). Frankfurt am Main: Suhrkamp.

Mommsen, K. (2011). Goethe's Relationship to the Turks as Mirrored in his Works.In Pera-Blätter (Vol. 20, pp. 4-5). Bonn: Max Weber Stiftung-Dt. Geisteswissenschaftliche Institute im Ausland.

Nehring, K. (1983). Adam Freiherrn zu Herbersteins Gesandtschaftsreise nach Konstantinopel. Ein Beitrag zum Frieden von Zsitvatorok (Südosteuropäische Arbeiten 78). München: Oldenbourg.

Neumann, C. (1735). LectionesPublicae. Von vier SubjectisDiaeticis, nehmlich von den hiesigen Gegenden gewöhnlichsten und durch menschliche Hülffe zu Stande gebrachten viererleyGeträncken, vom Thée, Caffee, Bier, und Wein... . Leipzig: Gottlob Benjamin Frommann.

Newald, J. (1883). Beiträge zur Geschichte der Belagerung von Wien durch die Türken im Jahre 1683. Wien: Kubasta und Voigt.

Özkurt, S. (1972). Die Türkenlieder und das Türkenbild in der deutschen Volksüberlieferung vom 16. bis zum 20. Jahrhundert (Motive. Freiburger Folkloristische Forschungen 4). München: W. Fink.

Pavord, A. (2003). Die Tulpe. Eine Kulturgeschichte. Frankfurt am Main, Leipzig et al.: Insel-Verlag.

Parvev, I. Ch. (1995).Habsburgs and Ottomans between Vienna and Belgrade (1683-1739) (East European monographs 431). New York: Columbia University Press.

Preibisch, W. (1908).Quellenstudienzu Mozarts "EntführungausdemSerail" Ein Beitrag zur Geschichte der Türkenoper. Halle a. d. S. Thesis. Report on the Turkish ambassador to Vienna (1720, March 18th). Retrieved from Wiener Diarium http://anno.onb.ac.at/cgi-content/anno?aid=wrz

Rigler, L. (1852). Die Türkei und deren Bewohner in ihren naturhistorischen, phisiologischen und pathologischen Verhältnissen vom Standpunkte Konstantinopel's ( 2 Vols.). Wien: C. Gerold.

Roider, K. A. (1982). Austria 'seasternquestion: 1700-1790. Princeton: Princeton Univ. Press.

Rosen, G. (1866). Geschichte der Türkei. Vom Siege der Reform im Jahre 1826 bis zum Pariser Tractat vom Jahre 1856 (2 Vols.) Leipzig: Hirzel.

Rouillard, C. D. (1941). The Turk in French history. thought and literature 1520-1660. A bibliography of pamphlets relating to the Turks, 1481-1660 (Études de littérature étrangère et comparée 13). Paris: Boivin.

Sale, G. (1734). The Koran: commonly called the Alcoran of Mohammed. London: Wilcox.

Schipperges, H. (1964). Die Assimilation der arabischen Medizin durch das lateinische Mittelalter. Sudhoffs Archiv. Zeitschrift für Wissenschaftsgeschichte. Beiheft 3. Wiesbaden: Franz Steiner Verlag.

Setton, K. M. (1991). Venice, Austria, and the Turks in the seventeenth century. Philadelphia: American Philosophical Society.

Teply, K. (1968). Kaiserliche Gesandtschaften ans Goldene Horn. Bibliothek klassischer Reiseberichte. Stuttgart: Steingrüber. 
Tietze, A. (Ed.) (1985). Habsburgisch-osmanische Beziehungen. Wien 26.-30. September 1983. Colloque sous le patronage du Comité internat. des études pré-ottomanes et ottomanes = Relations Habsbourg-ottomanes. Wiener Zeitschrift für die Kunde des Morgenlandes. Beiheft 13. Wien: Verlag d. Verb. d. Wiss. Ges. Österreichs.

Tuchman, B. (1978). Der ferne Spiegel-Das dramatische 14. Jahrhundert. Aus dem Amerikanischen von U. Leschak und M. Friedrich, 5. ed. Munich: dtv.

Uhlich, G. (1783). Geschichte der zweyten türkischen Belagerung Wiensbey der hundertjährigen Gedächtnißfeyer. Wien: Sonnleithner.

Unrest, J. (1957). Österreichische Chronik. In Karl Grossmann (Ed.), Monumenta Germaniae Historica Scriptores 6. Scriptoresrerum Germanicarum (Nova series 11). Weimar: Böhlau.

Wiegand, H. (1989). Hodoeporica. Zur neulateinischen Reisedichtung des sechzehnten Jahrhunderts. In Der Reisebericht. Die Entwicklung einer Gattung in der deutschen Literatur (pp. 117-139). Suhrkamp Taschenbuch, 2097. Frankfurt am Main: Suhrkamp.

Wiegand, H. (1993). Imago Turcae. Das Türkenbild der frühen Neuzeit im Lateinunterricht der Oberstufe. In Der Altsprachliche Unterricht: Arbeitshefte zu seiner wissenschaftlichen Begründung und praktischen Gestalt (pp. 12-31). Seelze-Velber: Friedrich. 